LIAMES, Campinas, SP, v. 19, 1-29, e019017, 2019

\title{
Functional typological approach to Shawi indeterminate pronouns
}

\author{
Luis Ulloa \\ suNY University at Buffalo, New York, United States \\ https://orcid.org/0000-0002-6263-4047
}

\begin{abstract}
This study describes the formation of indeterminate pronouns in Shawi, which is a class of proforms that can have interrogative, indefinite, and free relative senses. These interpretations are only distinguished through a class of clitics, e.g. $m a^{\prime}=t a$ (what, relative what), $m a^{\prime}=s h a$ (something), $m a=n t a$ (nothing). The first of these can be further modified to $m a{ }^{\prime} t a=k a$ (rhetorical what) and $m a^{\prime}=t a n a$ (whatever). As in other languages, this class of proforms can be categorized into a paradigm in which each member represents a general concept like person (who), thing (what), place (where), time (when), manner (how), etc. Comparing these forms reveals further internal structure. As such, Shawi indeterminate pronouns are analyzed and the clitics that can modify their interpretation are discussed.
\end{abstract}

KEYwORDS: Indeterminate; Interrogative; Indefinite; Rhetorical questions; Free relatives.

RESUMEN: Esta investigación describe la formación de los pronombres indeterminados en shawi. Esta clase de pronombre puede tener sentidos interrogativos, indefinidos, y relativos que solamente se distinguen con una clase de clíticos, e.g. $m a^{\prime}=t a$ (qué, lo que), $m a^{\prime}=s h a$ (algo), $m a=n t a$ (nada). El primero puede ser modificado aún más a $m a^{\prime} t a=k a$ (qué retórico) y $m a^{\prime}=$ tana (lo que sea). Como en otros idiomas, esta clase de pronominales puede ser clasificada en un paradigma en el que cada miembro representa un concepto general como persona (quién), cosa (qué), lugar (dónde), tiempo (cuándo), manera (cómo), etc. La comparación de estos elementos demuestra una estructura interna más extensa. Por eso, los pronombres indeterminados en shawi son analizados y también se habla sobre los clíticos que pueden modificar su interpretación.

Palabras Clave: Indeterminado; Interrogativo; Indefinido; Preguntas retóricas; Relativos libres.

\section{Introduction}

Shawi, also known as Chayahuita (iso 639-3: cbt), is one of two extant languages in the Kawapanan family, as established in Beuchat \& Rivet (1909), and further discussed in Rivet \& Tastevin (1931), Valenzuela (2011b), and Rojas-Berscia (2019a: 169-195). In terms of political divisions, Shawi is mainly spoken in the Alto Amazonas and Datem del Marañón provinces in the Loreto Region of Peru, with some enclaves in the Lamas province in the San Martín region of Peru. Shawi can be divided into three varieties: Cahuapanas, 
Sillay (aka Chayahuita), and Paranapura (aka Balsapuerto) whose distribution roughly corresponds to the rivers that bear the same names. ${ }^{1}$

Shawi is reported by Crevels (2007: 120) to have 7,800 to 12,000 speakers out of an ethnic group of the same size. An unfortunately dateless summary given by the Peruvian Ministry of Culture's Database of Indigenous or Original Peoples (BDPI) states: "According to data obtained by the Ministry of Culture, the population of Shawi communities is estimated to be 25, 239 persons" (BDPI). However, not all who identify as Shawi can speak the language. As Rojas-Berscia (2019a: 377) reports, mestizo influence is triggering the loss of Shawi vernaculars in many villages. Furthermore, Shawi families are moving from communities to cities and children are encouraged to only speak Spanish.

Although no full grammatical description of Shawi exists yet, specific topics have been examined. For instance, SIL linguists have provided phonological (Hart, Hart \& Powlison 1976) and discourse structure (Hart \& Hart 1981) descriptions, as well as a dictionary with a small sketch (Hart 1988), and a collection of traditional Shawi legends (Hart; Pua \& Pua 1996). In this century, there has been increased interest in Shawi from secular researchers. For instance, Barraza de Garcia's (2005) dissertation provides a description of the verbal morphology, ${ }^{2}$ and Rojas-Berscia has published several works, including his 2013 licentiate thesis which explores causation and his recent dissertation which explores several topics in synchronic and diachronic variation with a focus Shawi and Kawapanan languages (Rojas-Berscia 2019a).

\section{An overview of the phenomena}

The phenomena under consideration here are indeterminate pronouns in Shawi which includes interrogative and indefinite pronouns, and free relatives. In other words, the focus is on those interrogatives that are found in content questions. This paper does not examine polar question marking, which Hart (1988: 293) ${ }^{3}$ reports is formed by ending an utterance with a particle, $t i$, as in (1). However, in the Cahuapanas variety, polar questions are formed with $=k a$ as in (2), and further corroborated by Rojas-Berscia (2019a: 132).

${ }^{1}$ According to Rojas-Berscia (2019a: 46), these are: "Paranapura: Cachiyacu, Armanayacu, Sabaloyacu, Yanayacu [Rivers], and some isolated groups close to the Lower Huallaga highway and the Shanusi River.

"Cahuapanas: Cahuapanas River.

"Chayahuita: Sillay River, Pueblo Chayahuita, and some villages on the margins of the upper Paranapura."

2 "[This] analysis is limited to the verbal system of simple sentences of the Shawi variety spoken in the banks of the Sillay river" (Barraza 2005: 7; translation is my own).

${ }^{3}$ Barraza (2005) does not discuss polar question formation. Rojas-Berscia (2013) does mention it, but references Hart (1988), like is done here. Rojas-Berscia (2019a) only mentions polar questions in the Cahuapanas variety.

${ }^{4}$ The quality of the vowel now represented by grapheme $<\mathrm{e}>$ has been analyzed to be /u/ in Hart, Hart \& Powlison (1976) (for which Hart (1988) used <ë>), /i/ in Barraza (2005), and /9/ in Rojas-Berscia (2019a). Likewise, the phoneme represented by the grapheme $<\mathrm{u}>$ has been claimed to be $/ \mathrm{v} /$ by Hart \& Powlison (1976) (for which Hart (1988) used $<0>$ ), /u/ by Barraza (2005), and /o/ by Rojas-Berscia (2019a). It should be noted that only Rojas-Berscia's (2019a) conclusions are drawn from an acoustic analysis (ibid., 58). Notwithstanding, all are in agreement that $<\mathrm{i}>$ and $<\mathrm{a}>$ represent $/ \mathrm{i} /$ and $/ \mathrm{a} /$. A community-driven orthographical shift, changed Hart's (1988) $<\ddot{e}>$ and $<_{0}>$ to $<\mathrm{e}>$ and $<\mathrm{u}>$. Since Hart's (1988) dictionary and the NT both come from SIL fieldwork, they both use the same (obsolete) orthography. The orthography in examples from those sources has been updated (Rojas-Berscia 2019a: 64). 


\begin{tabular}{|c|c|c|c|}
\hline $\mathrm{ku}$ & kema $^{4}$ & teranta' & nitute-ran=we', \\
\hline NEG & $2 \mathrm{MIN}$ & either & know-IND. $2 \mathrm{MIN}=\mathrm{NEG}$ \\
\hline
\end{tabular}

You didn't know either, right?

Hart (1988: 293)
(2) ¿yamure-'pa' pa'-pi=ka?
Balsapuerto ${ }^{5}$-AND go-IND. $3 \mathrm{AUG}=\mathrm{Q}$
Did they go to Balsapuerto?

Notebook 1: $61^{6}$

The primary interest in the topic, comes from the fact that what appeared to be interrogative pronouns exhibited a high degree of variation in form. Below, a list of some of these words, gathered from the Shawi New Testament (NT), are presented,

(3) incha, inseketa', insekesuna, inkema, inkenta', insu', insunta', insuna, insusuna, inta', intuwasu', ma'marecha, ma'mareta', ma'pitacha, ma'puchinsu', ma'puchinsuna, ma'su', ma'ta', manta', unpuatumacha, unpuatunta', unpurusuna, unpupinta', unpupinsuna', etc...

Even though all this variation is present, there are formative elements which are shared and reveal internal structure within the pronouns. These include formatives: in-, insu-, ma-, unpu-, -pita-, =ta', =cha', =nta', =su, =suna. The initial elements convey conceptual bases (person, thing, etc.), the medial elements are NP modifiers (case marking, plural marking, etc.), and the final elements are indeterminate clitics which assign different interpretations. Their functions will be discussed in more detail in sections 4-10.

This paper is laid out as follows. In section 3, the terms used here and how they apply to Shawi will be discussed. In section 4, the categories that can be expressed with indeterminate pronouns are discussed. Section 5 discusses rhetorical question marking. In section 6, indefinite pronouns are discussed. Section 7 goes more in-depth into the negative indefinite pronoun marker and scalar implicatures as well. Section 8 takes a look at free relatives. In section 9, constructions with the marker $=s u$ are discussed. Section 10 looks at other uses for indeterminates. Section 11 provides some concluding remarks. Finally, an appendix provides all attested indeterminate pronouns.

\section{Preliminaries to the study}

\subsection{Ontological base}

As Bhat (2004: 153) states: "Proforms [non-personal pronouns] occur in the form of a set of paradigms in most languages. The general characteristic of these paradigms

${ }^{5}$ To be clear, yamure comes from yamura-i', and actually translates into 'salt-water'. Balsapuerto is a district capital located on the banks of the Cachiyacu River, which itself is a Quechua word that also translates to 'salt-water.' This area is where Shawi mine salt (Fuentes, 1988; Rojas-Berscia 2019a).

${ }^{6}$ All references to field notes are from Ulloa \& Pinedo Escobedo (2017) and can be found at The Archive of the Indigenous Languages of Latin America (ailla.utexas.org). Texts cited here can also be found there. Text translations from Shawi to Spanish were done by Segundo Pinedo Escobedo. All translations from Spanish to English were done by the author. 


\section{ULLOA - FUNCTIONAL TYPOLOGICAL APPROACH TO SHAWI...}

is that each of them represents a set of general concepts like person, thing, place, time, manner, property, etc." In Haspelmath's (1997) typological study of indefinite pronouns, these paradigms are given the name series (taken from Veyrenc 1964, cited in Haspelmath 1997: 21), and the general concepts are formalized under the term ontological categories ${ }^{7}$ (from Jackendoff 1983: 51).

The motivation behind this is that indefinite pronouns most commonly consist of a stem, or base, indicating an ontological category and a formal element shared by all members of an indefinite pronoun series. Likewise, all series share a formal element. For instance, the ontological base, -body represents the ontological category of 'person' in all indefinite series, namely the some-, any-, and no-series (cf. somebody, anybody, nobody).

Adapting this concept to Shawi indeterminates proves useful, as they consist of a base indicating the ontological category (in-for person; $m a$ '- for thing; etc.) and a clitic denoting whether it is interrogative $\left(=t a^{\prime}\right)$, indefinite $(=s h a)$, negative indefinite $\left(=n t a^{\prime}\right)$.

Also worthy of mention is that some languages have more ontological distinctions in proforms than others. Thus, according to Haspelmath (1997: 30), some languages also express a determiner category, like English which. However, the validity of 'determiner' as a cross-linguistic category is controversial. Therefore, in order to avoid using a term whose validity is dubious, words like English which are called adnominals.

\subsection{Indeterminate pronouns}

In a number of Australian languages, such as Ngiyambaa (Donaldon 1980), interrogative and indefinite pronouns share the same ontological base, but they are bound and must be modified by contrasting 'knowledge clitics' to be used as interrogatives, or indefinites. For instance, minja- 'what/something' appears as minja-wa: 'what?' or as minjay-ga: 'something' (Donaldson 1980: 148-50). Therefore, Donaldson groups these pronouns together into one class, which she calls indeterminate. Bhat (2004: 227) proposes a notion of informational gap to describe this similarity in form and function between interrogatives and indefinite.

Likewise, interrogative and indefinite pronouns are only distinguished through a class of clitics in Shawi. Therefore, given the similarities, the same label indeterminate is used to classify the Shawi pronouns and the clitics that modify the ontological bases that they are composed of. In other words, the indeterminate pronoun ma'ta (what) is composed of the ontological base $m a^{\prime}$-, which expresses the category of person; and the indeterminate clitic $=t a$.

\subsection{Indeterminate clitics}

Shawi needs two, but can have up to three, different kinds of elements in an indeterminate pronoun. The first (leftmost) is a base expresses the ontological category, the second slot is optional and has NP modifiers, while the third is a clitic which assigns

${ }^{7}$ As stated Haspelmath (1997: 21): “equivalent terms are epistemological category (Durie 1985: ch. 6) and knowledge category (Mushin 1995)." 
different interpretations. That the final element is a clitic becomes clear when one considers that indeterminate pronouns can be restructured into two parts so that a constituent can occur between them, c.f. examples (4) and (5) below.

$$
\begin{array}{lll}
\text { ¿ma'=ta' } & \text { pa'an }^{8} \text {-pu } & \text { pa'n-an? } \\
\text { what=INT } & \text { buy-POT.2MIN } & \text { go-IND.2MIN }
\end{array}
$$

What have you gone to buy? ${ }^{8} \quad$ Notebook 1: p. 54

$$
\begin{aligned}
& \begin{array}{lllll}
\begin{array}{l}
\text { ¿unpu-ran=ta } \\
\text { do.what-IND.2MIN=INT }
\end{array} & \begin{array}{l}
\text { iya-ra? } \\
\text { brother-DIM }
\end{array} & \begin{array}{l}
\text { kema } \\
2 \mathrm{MIN}
\end{array} & \text { ¿ma } & \text { khanu=ta' } \\
\text { illness=INT }
\end{array} \\
& \begin{array}{l}
\text { ya'u-te-rin-ke? } \\
\text { exist-vM-IND.3MIN-OBJ.2MIN }
\end{array} \\
& \text { What's up friend? What illness do you have? }
\end{aligned}
$$

The sentence in (4) contains the interrogative $m a^{\prime} t a$ ' as a single unit, while in (5) the noun kanu 'illness' occurs between the formatives $m a$ '- and $=t a$ ', which illustrates that the latter is a clitic.

\subsection{Free relative}

Free relative clauses (FRs), also known as free or headless relatives, are elements which are very similar to relative clauses, but appear to have no head. Moreover, the first element in FRs bears a striking resemblance to interrogative pronouns, as in (6) below,

(6) You should return what you have finished reading.

As Caponigro, Torrence \& Cisneros (2013) report, FRs are attested in Mixtec, IndoEuropean, Finno-Ugric, Semitic, Mayan languages, and Haida. Therefore, they "define FRs in a way that provides a clear test for identifying them within a language and across languages" (p. 73). Thus, FRs are strings that satisfy the following three properties,

(i) Lexical property: FRs must contain a wh-word

(ii) Syntactic property: FRs are embedded clauses with a gap in argument or adjunct position

(iii) Semantic property: FRs can always be replaced with truth conditionally equivalent NPs or PPs (or oblique or adverbial constituents)

Since this definition is meant to be applicable cross-linguistically, we define free relatives in Shawi based on those properties.

In English, it can be difficult to distinguish free relatives from embedded questions as in, I wonder where John is going. However, this does not seem to be an issue in Shawi

${ }^{8}$ This verbal root can be used to both mean 'buy' and 'sell. ' 


\title{
ULLOA - FUNCTIONAL TYPOLOGICAL APPROACH TO SHAWI...
}

as questions cannot be embedded. Example (7) illustrates that the equivalent of embedded questions in English are quotatives in Shawi.

$\begin{array}{llll}\text { (7) ¿ma kemapi=ta' } & \text { napu-te-ran-su'? } & \text { ku } & \text { ka-su' } \\ \text { what person=INT } & \text { say-VM-IND.2MIN-REL } & \text { NEG } & \text { 1 MIN.EXCL-FOC } \\ \text { nuwite-rawe', } & \text { ite-rin } & \text { ya'ipiya } & \text { natan-pi. } \\ \text { know-IND.1MINNEG } & \text { say-IND.3MIN } & \text { all } & \text { hear-IND.3AUG }\end{array}$

But he denied it in front of them all: "I don't know what you're talking about!" (lit. Which person is the one you told? I do not know, he said. All heard.)

Matthew 26:70

\section{The ontological categories in Shawi}

This section describes the ontological categories which indeterminates may express in Shawi. Additionally, hypotheses about their possible compositional makeup will be discussed. First, the ontological classes which appear to be based on the pronoun in(who) will be discussed (section 4.1). Afterwards, the ones based on ma' (thing) will be presented (section 4.2). Finally, the ontological categories based on the indeterminate verb stem unpu- will be considered (section 4.3).

\subsection{Composed from in- (3)}

The formative for the ontological categories of person, location and direction seem to be based on the pronoun in-. This pronoun bears a striking resemblance to the pronoun ina, which can be used as a third person pronoun, a medial demonstrative pronoun, or as an anaphor for an event when followed by the ablative postposition keran. This pronoun is itself historically composed of the deictic morpheme $i$ - and the third person marker -na (Rojas-Berscia 2019a: 120).

\subsection{1. in- insu- (person)}

In Shawi, the ontological category of person can be expressed by two elements. The first of these is in-, while the second is insu-. Thus, one finds insunta' (nobody) where one would expect inta'. This gap is most likely due to the fact that the form inta' (as in (8) below) is already in use as the standard question form of the 'person' category (who).

$\begin{array}{lll}\text { ¿in=ta }^{\text {wen }} \text { wen } & \text { pei-parin }{ }^{9}-\mathrm{ke} \\ \text { who=INT come-IND.3MIN } & \text { house-POSS.2MIN-LOC } \\ \text { Who came to your house }{ }^{9} & \end{array}$

Who came to your house? ${ }^{9}$

\author{
Notebook 1: p. 54
}

${ }^{9}$ Although Hart (1988) and Rojas-Berscia (2013, 2019a) do not report -parin as a second person possessive suffix, Barraza (2005: 90-91, 102) does and it is common in the Cahuapanas variety. This form is innovative and its use is probably due to disambiguate between the second and third person. 

(9) $\mathrm{ku}$
insu $=$ nta
napu-pi=we'
NEG who $=$ NEG.INDEF
say-IND. $3 \mathrm{AUG}=\mathrm{NEG}$

No one said that.

Notebook 1: p. 58

\subsection{2. insu- (adnominal)}

The form insu- is composed of in- $+-s u^{\prime}\left(\right.$ NOMLZ $\left.^{10}\right)$ and it has two functions. It can either be used as the ontological base for 'person' or as an adnominal modifier as discussed in $\$ 4.1 .1$. It is possible for a nominal element to occur between the ontological base and the indeterminate clitic, like in (10) below. However, the strategy in (11) seemed more natural for the speaker.

$\begin{array}{lll}\text { ¿insu } & \text { ni'ni'=ta } & \text { chimin-in }{ }^{11} ? \\ \text { which=INT } \quad \operatorname{dog} & \text { die-IND.3MIN } \\ \text { Which dog died } ?^{11} & \end{array}$

Notebook 1: p. 64

$\begin{array}{lll}\text { ¿insu=ta } & \text { ni'ni' } & \text { chimin-in? } \\ \text { which }=\text { INT } & \text { dog } & \text { die-IND.3MIN } \\ \text { Which dog died? } & \end{array}$

Notebook 1: p. 64

\subsection{3. inseke- (location)}

The form inseke-, which is used for location, seems to be composed of in- + -su' (NOMLz) $+-k e$ (locative). Here, there is a process of regressive vowel harmony, where the $<\mathrm{u}>$ of $-\mathrm{su}$ ' changes to $<\mathrm{e}>,{ }^{12}$ yielding inseke- and not *insuke-.

\author{
¿inseke $=$ ta ni-sa-rawe? \\ where $=$ INT be-PROG-IND.1MIN.EXCL? \\ Where are we?
}

where=REL grab-SEQ.IMPRS take-JUS.IMPRS

One should grab it (the ball) wherever to take it.
Notebook 1: p. 59

\author{
Notebook 1: p. 68
}

${ }^{10}$ Hart (1988: 267, 287) and Barraza (2005:170-173) analyze this suffix as a focus marker that can also relativize verbs. More recently, Rojas-Berscia (2019a: 116; 2019b) has analyzed this as a general weak nominalizer that relativizes verbs and topicalizes nouns. In this particular case, it is a diachronic process.

${ }^{11}$ In Shawi / $/$ is neutralized as [n] word-initially and after a glottal stop (Rojas-Berscia, 2019a: 57). Neutralization goes so far when a suffix that begins with /f/ -like -rin (cf. ite-rin, tell-ind.3min)-attaches to a root ending in /n/ -LIKE CHIMIN- (CF. CHIMIN-PUN, DIE-POT.2/3MIN)-IT IS ELIDED, LIKE IN (11) ABOVE.

${ }^{12}$ This process is discussed for the suffix -te (valence marker) in Barraza (2005: 59-63). 


\subsection{4. intupa- (direction)}

This base is used for the ontological category of direction, cf. English whither. Additionally, the limitative case, -ware can be attached to give a subtle change in meaning. This ontological base has its origins in Proto-Kawapanan (PK), whereby the PK *nupa=ta (where) is preceded by in-producing a phonological change where the second $/ \mathrm{n} /$ forms a full closure, i.e. [t] (Rojas-Berscia 2017: 483).

$$
\begin{array}{llll}
\text { ¿intupa }=\text { ta } & \text { ina } & \text { kunsha-ru'sa } & \text { pa'nin? } \\
\text { whither=INT } & \text { that } & \text { squash-PL } & \text { go-IND.3MIN }
\end{array}
$$

Where did those squashes go to?

Of the man that became the moon, 05:42

$$
\begin{array}{ll}
\text { intupa-ware }=\text { ta } & \text { pa'-sa-ran? } \\
\text { to.where-LIM=INT } & \text { go-PROG-IND.2MIN }
\end{array}
$$

Until where are you going?

Notebook 1: p. 56

\subsection{Composed from $m a$ ' (thing)}

\subsection{1. $m a$ '- (thing, adnominal)}

In Shawi, $m a^{\prime}$ can denote the ontological categories of thing, and can be used adnominally, cf. What park do you want to go to? . In (16) below, we see its use as an interrogative, while in (5) repeated here as (17), we see the adnominal use.

$$
\begin{gathered}
¿ \mathbf{m a}=\mathbf{t a} \quad \text { se'ka-ran? } \\
\text { what }=\text { INT } \quad \text { grab-IND. } 2 \mathrm{MIN} \\
\text { What are you grabbing? }
\end{gathered}
$$

Notebook 1: p. 55

(17) ¿unpu-ran=ta do. what-IND. $2 \mathrm{MIN}=$ INT brother-DIM $2 \mathrm{MIN}$ what illness $=$ INT ya'u-te-rin-ke? exist-VM-IND.3MIN-OBJ.2MIN

What do you have? What illness do you have?

Notebook 1: p. 17

It is unclear what the difference between insu- and $m a$-is when they are used adnominally. However, it can be conjectured that this variation is like the difference in English between, which and what, e.g. Which park are we going to? vs. What park are we going to?

\subsection{2. ma'mare- (purpose)}

The next ontological category which Shawi distinguishes is purpose or reason, which seems to be composed of $m a^{\prime}$ - and the purposive/benefactive -mare'. 
$\begin{array}{ll}\text { (18) ¿ma'mare'=ta } & \text { pa'n-in? } \\ \text { for.what }=\text { INT } & \text { go-IND.3MIN }\end{array}$

For what (reason) did he leave?
Notebook 1:p. 64

pan-iun

go-IND.3MIN:NEG

Notebook 1: p. 64

\subsection{Composed from unpu- (indeterminate verb stem)}

The indeterminates that follow have the same base as the indeterminate verb unpu-. The verb uпри- is used in interrogative as well as indefinite contexts. Using it expresses something like 'do what', or 'why be'. Hart (1988: 155) gives an example with both interrogative and indefinite uses of unрu-, which is repeated as (21) below.

$$
\begin{array}{lll}
\text { iunpu-ran=ta } & \text { a'shicha } & \text { itu-pi } \\
\text { be.why-IND.2MIN=INT } & \text { aunt } & \text { say-IND.3AUG }
\end{array}
$$

They said: "What is going on with you, aunt?" (¿Que tienes?)

The achiote and huito sisters, 06:13

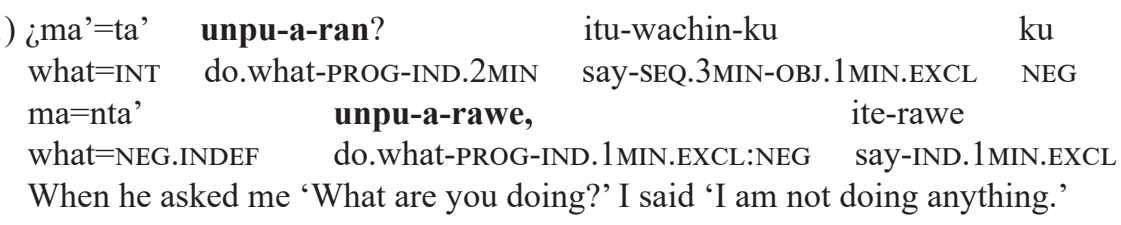

\subsection{1. unpu- (quantity)}

The form of the base for quantity, unpu-, is identical to that of the indeterminate verb stem in the previous section, but it does not have any verbal morphology. Like $m a$ - and insu-, it can be used adnominally.

$$
\begin{aligned}
& \text { ¿unpu=ta isu pa'te-rin? } \\
& \text { how.much=INT this cost-IND.3MIN } \\
& \text { How much does this cost? }
\end{aligned}
$$

Notebook 1: p. 55

$$
\begin{aligned}
& \text { ¿unpu nunsha }=\text { ta yawe-te-rin-ke? } \\
& \text { how.many canoe }=\text { INT exist-VM-IND.3MIN-OBJ.2MIN } \\
& \text { How many canoes do you have (exist for you)? Notebook 1: p. } 55
\end{aligned}
$$

Apparently, it can also modify verbs and in the sense below, it conveys the category of manner which can also be expressed with unpuin- (see §4.3.3) 


\section{ULLOA - FUNCTIONAL TYPOLOGICAL APPROACH TO SHAWI...}

(24) iunpu a'pani-te-re' $=$ ta

how.many answer-VM-IND.IMPRS=INT

How does one answer? (How is the phone used?) Notebook 1: p. 55

\subsection{2. unpuru'- (time)}

The formative unpuru'-, expresses the notion of time. Like many other indeterminates, unpuru'- is also decomposable although its composition is not transparent. The original meaning of the classifier, -ru', which denotes the notion of 'many' (Hart 1988: 260) must have been semantically bleached over the years. In (25) below, we see unpuru'- occurring with $=n t a$, producing never .

$$
\begin{array}{lll}
\mathrm{ku} & \text { unpuru=teranta } & \text { wen-an } \\
\text { NEG } & \text { when=NEG.INDEF } & \text { come-IND.2MIN }
\end{array}
$$

You never come / came.

Notebook 1: p. 65

\subsection{3. unpuin- (manner/property)}

The indeterminate pronoun unpuin- expresses the categories of manner (how) and property (what.sort.of). This seems to be composed of unpu- and -pin $\sim-n p i$, cf. unpupinsuna (type), unpupinta (what type?), isanpi (this type) inanpi (that type) (Hart, 1988: 462). A lenition process from $/ \mathrm{p} /$ to [w] has now ended in elision. ${ }^{13}$

$$
\begin{array}{llll}
\text { ¿unpuin=ta } & \text { tanan-ke } & \text { ma'sha } & \text { yuni-re? } \\
\text { how=INT } & \text { forest-LOC } & \text { animal } & \text { search-IND.IMPRS }
\end{array}
$$

How does one search for animals in the forest? Notebook 1: p. 57

$$
\begin{aligned}
& \text { ¿unpuin=ta pei yawe-te-rin-ken? } \\
& \text { what.type=INT house exist-VM-IND.3MIN-OBJ.2MIN } \\
& \text { What type of house do you have? / How is your house? }
\end{aligned}
$$

Notebook 1: p. 57

\subsection{4. unpan- (reason)}

The base unpan- conveys the category of reason (why). Although its compositional makeup is difficult to confirm with any certainty. The form suggest that it may be composed of ипри and a suffix -an. While there is no suffix -an, there are suffixes -ana (CLS.around) and -(a)nta (again).

${ }^{13}$ The sociolinguistic dimension of this process is described in Rojas-Berscia (2019a: ch. 9) 


\begin{tabular}{lllll}
\hline (28) yunki-pi & ma'shu-ru'sa & iunpan=ta & aya-teranta-pi & [ma'su] \\
think-IND.3AUG & elder-PL & why=INT & lose-even-IND.3AUG & [um] \\
wi'n-in-pita? & {$[\mathrm{ma}$ 'su] } & & & \\
child-POSs.3MIN-PL $\quad[\mathrm{um}]$ & & \\
The elders [wondered]: Why are they losing their children? & \\
Tunpanama and the whale, $07: 01$ &
\end{tabular}

The verb in example (28) suggests that it may be -nta and that the same process described in $\S 7$ is the reason. If this were the case, why is it unpan $=t a$ and not unpanta $=t a$ ? A process of haplology would likely have deleted one of the [ta] sequences.$^{14}$ Homorganic progressive nasal assimilation is common in Shawi, oftentimes unpana is used instead, like in (29).

$$
\begin{aligned}
& \text { (29) } \text { unpan=a kema peisha na'na-ran } \\
& \text { why }=\text { INT } 2 \text { MIN old.woman cry-IND.2MIN }
\end{aligned}
$$

Why are you crying, old lady?

The woman and the iguana-man, 01:18

\subsection{Ontological categories or case assignment?}

Given that most of the ontological categories can be decompositioned into either $i n(s u$ )-, ma-, or unpu- and a case marker (with the exception of -ru, §4.3.2; -(p)in, §4.3.3; and -(a)nta, §4.3.4), it raises the possibility of another analysis. Under this analysis, Shawi would only have three basic indeterminate pronouns which can then be modified by the case system of the language to provide further categories. Supporting evidence from this comes from the fact that other cases can be used to express even more categories. Furthermore, other NP modifiers can attach themselves to give more variety in meaning. The next examples show the instrumental, genitive, ablative, comitative, and ergative cases being used to 'form' ontological bases.

¿ma'-ke=ta taya tepa-rin?
what-INST=INT crocodile kill-IND.3MIN
What is the crocodile killed with?

Notebook 1: p. 56

$$
\begin{aligned}
& \text { ¿in-ken=ta isu nunsha? } \\
& \text { who-GEN=INT this canoe } \\
& \text { Whose canoe is this? }
\end{aligned}
$$

Notebook 1: p. 54

$$
\begin{aligned}
& \text { ¿inse-ran=ta kema? } \\
& \text { where-ABL=INT 2MIN } \\
& \text { Where are you from? }
\end{aligned}
$$

\footnotetext{
${ }^{14}$ Haplology also occurs in (7), one should expect nuwite-rawe $=w e$ '.
} 


\section{ULLOA - FUNCTIONAL TYPOLOGICAL APPROACH TO SHAWI...}

(33)

in-eke ${ }^{15}=$ ta nun-sa-ran?

who-COM.2MIN=INT talk-PROG-IND.2MIN

Who are you talking with? ${ }^{15}$

Notebook 1: p. 54

(34)

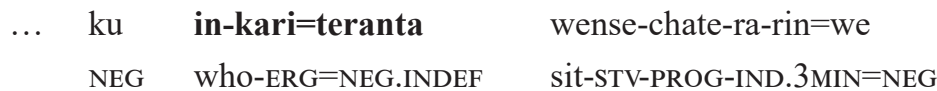

...[As soon as you enter it,] you will find a colt there that has never been ridden... (lit. No one / Not even one has sat on it.)

Mark 11:2

$$
\begin{array}{lllll}
\text { ¿intuwa=ta } & \text { pa'n-in } & \text { sa'a-we? } & \text { ¿ma-kari=ta } & \text { man-in? } \\
\text { whither=INT } & \text { go-IND.3MIN } & \text { wife-Poss.1MIN.EXCL } & \text { what-ERG=INT } & \text { grab-IND.3MIN }
\end{array}
$$

Where did my wife go? What grabbed her?

The woman and the spirit of the stone, 07:31

Counter-arguments for such an analysis might mention the fact that elements have fused in unpuin- (how) and unpan- (why); and the original meaning of -ru in unpuru- is no longer transparent. One should take note that these are all formed from unpu-. Perhaps, this element is older than in- and $m a-$, which may explain this.

\subsection{Other NP modifiers}

Other NP modifiers such as -pita (plural for kinship relations, pronouns, and relative clauses) and nominal copulas can be used to modify indeterminate pronouns.

$$
\begin{array}{ll}
\text { ¿in-pita }=\text { ta } & \text { napu-pi? } \\
\text { who-PL }=\text { INT } & \text { spoke-IND. } 3 \text { AUG }
\end{array}
$$

Who (pl) spoke?

Notebook 1: p. 60

$$
\begin{array}{ll}
\ldots \quad \text { in-ken=ta } & \text { kema-su? } \ldots \\
\text { who-coP.2MIN=INT } & \text { 2MIN-FOC } \\
\ldots \text { Who are you?... } &
\end{array}
$$

John 21:12

\section{Rhetorical interrogative marker}

Hart (1988: 293-294) reports a rhetorical interrogative marker $=c h a$ as in (38). The contrast between $=t a^{\prime}$ and $=c h a^{\prime}$ can be illustrated with the difference between (39) and (40).

${ }^{15}$ While the comitative usually begins the phoneme $/ \mathrm{r} /$, or $\langle\mathrm{r}>$; the same process that is described in footnote 11 occurs here. 


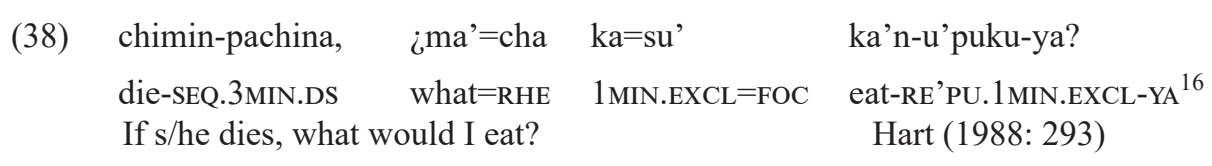

¿in-kari=ta' ya-sha'wa-rapi-rin-su'?

who-ERG $=$ INT DES-tell-DIST-IND.3 MIN-REL

[So Simon Peter gestured to this disciple to ask Jesus] who it was he was referring to (lit. who is the one he wanted to tell about?) John 13:24

$\begin{array}{lrr}\text { ¿in-kari=cha } & \text { nitutu-wachin } & \text { nate-re'pu-ya? } \\ \text { who-ERG=RHE } & \text { know-SEQ.3AUG.DS } & \text { believe-RE'PU-YA } \\ \text { Who can understand it? } & \text { John 6:60 }\end{array}$

In (39) the context is that Jesus has just revealed to his disciples that one among them will betray him. The disciples want to know who this person is and so they ask Simon Peter to ask Jesus. This question is one that has an answer or at least one where it is assumed that the addressee will know the answer. However, in (40) Jesus has declared that his body is the bread that comes down from heaven and that all that wish to have eternal life must eat it. Upon hearing this, his disciples ask themselves, i.e. rhetorically, if anyone can believe such a lesson.

While the marker $=$ cha is reported by Hart (1988) and frequent in the NT corpus, it was impossible to elicit it in the field. Nonetheless, the rhetorical function is still expressed through $=k a$, the marker used in polar questions. However, it should be noted that $=k a$ is only present in the Cahuapanas variety and is likely a borrowing from Aguaruna (RojasBerscia 2019a: 132). Example (2) showing how polar questions are formed with $=k a$ is repeated below as (41), while (42-47) illustrate its use in rhetorical questions.

$$
\begin{aligned}
& \text { ¿yamure-'pa' pa-pi=ka? } \\
& \text { Balsapuerto-AND go-IND.3=Q } \\
& \text { Did they go to Balsapuerto? }
\end{aligned}
$$

Notebook 1: p. 61

$$
\begin{aligned}
& \text { ¿unpuin=ta'? } \\
& \text { how=INT } \\
& \text { How is it? (¿Cómo es?) }
\end{aligned}
$$

Notebook 1: p. 60

${ }^{16}$ The -re'pu verbal paradigm has not been discussed in any previous description. Since it occurs in the same slot as modal markers, one can surmise that it is an irrealis marker, although the specific mood remains a mystery. In example (38), the same elision noted on footnote 11 occurs and there is regressive vowel harmony from the person marker $-k u$. That $-y a$ is not part of the paradigm becomes clear from $(\alpha)$ below; and in fact, placing -ya yielded ungrammatical utterances.

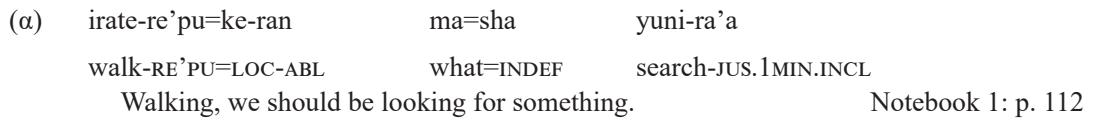


(43) ¿unpuin $=\mathrm{ta}=\mathbf{k a}$ ?

how $=\mathrm{INT}=\mathrm{Q}$

How might it be? (¿Cómo será?)

Notebook 1: p. 60

(44) pa-'a

pa-nta-'a

wa'wa-ru'sa

ni'-ku-nta'-a'

go-JUS.1 MIN.INCL

go-UP-JUS.1MIN.INCL

child-PL

See-TRANS-UP-JUS.1MIN.INCL

¿ma'-pita-n=ta=ka ni-sa-pi?

what-PL-UP $=$ INT $=\mathrm{Q} \quad$ do-PROG-IND.3AUG

Let us go up there and see the children, what could they be doing?

The fox and the star-woman, 04:11

$\begin{array}{llll}\text { isu } & \text { nunsha-ru'sa } & \text { insu }=\mathrm{ta}=\mathrm{ka} & \text { ina-ken? } \\ \text { this } & \text { canoe-PL } & \text { which }=\mathrm{INT}=\mathrm{Q} & 3 \mathrm{MIN}-\mathrm{GEN}\end{array}$

These canoes, which one might it be his?

Notebook 1: p. 54

$$
\begin{array}{lll}
\text { unpan }=\mathrm{a}=\mathrm{ka} & \text { mu'ten } & \text { ni'-te-ra }=\mathrm{u} \\
\text { why }=\mathrm{INT}=\mathrm{Q} & \text { head:POSs.3MIN } & \text { see-VM-IND. } 1 \mathrm{MIN} \cdot \mathrm{EXCL}=\mathrm{NEG}
\end{array}
$$

Why can I not see her head?

Filmer finds the mother spirit of the forest, 04:42

Like other indeterminate elements, $=k a$ can be used to circumscribe elements under its scope, like (47) below.

$$
\begin{aligned}
& \text { ¿ma' }=\text { ta ni }=\mathrm{ka} \quad \text { mama'-pari ni-sa-tun? } \\
& \text { what }=\text { INT } \quad \mathrm{do}=\mathrm{Q} \text { mother-POss.2MIN do-PROG-SUBORD.3MIN }
\end{aligned}
$$

The fox and the star-woman, 04:06

\section{Indefinite pronouns}

In Haspelmath (1997), indefinite pronouns are defined through two criteria. The first criterion is a formal one, which means that the form in question must be pronominal and not a content word, which is used in a broad sense that includes proforms for other lexical classes, such as adverbials like 'somewhere', 'somehow', etc. The second criterion is a functional one, this means that the pronoun in question must have indefinite reference.

Haspelmath (1997) distinguishes nine types of functions of indefinite pronouns for the purpose of cross-linguistic comparison. Not all of the functions are formally distinguished in every language. While each function may not be attested in a given language, crosslinguistically they are all attested and therefore justified. The functional categories and example sentences are provided below. 
1. specific, known to the speaker

(a) Somebody called while you were away: guess who!

2. specific, unknown to the speaker

(b) I heard something, but I couldn't tell what kind of sound it was.

3. non-specific, irrealis

(c) Please try somewhere else.

4. polar question

(d) Did somebody/anybody/nobody tell you about it?

5. conditional protasis

(e) If you see anything/something, tell me immediately.

6. standard of comparison

(f) In Freiburg the weather is nicer than anywhere in Germany.

7. direct negation

(g) Nobody knows the answer.

8. indirect negation

(h) I don't think that anybody knows the answer.

9. free choice

(i) Anybody can solve this simple problem.

In Shawi, indefinite pronouns can be created with the morpheme $=s h a$. However, its use is limited to in- (who) and ma- (what). This suggests a recent grammaticalization. Upon first glance, it looks like Shawi does not actually have indefinite pronouns, but instead uses generic nouns (e.g. 'person,' 'one,' etc.) to express indefiniteness. However, since insha is used as 'somebody' and not kemapi (person), it appears that =sha is being reanalyzed as a marker of indefiniteness. Negative indefinites (nobody, nothing, etc.) are formed using $=n t a$, and, like all other negative elements in Shawi, are preceded by the particle $k u(\mathrm{NEG})$ and ended by $=w e$ ' (NEG) on the verb. Below, examples are given that show which functional categories of indefinite pronouns are present in Shawi. Those that are not present will not be mentioned. This does not mean that they cannot be expressed, only that they are not expressed with indefinite pronouns.

2. specific, unknown to speaker

$$
\begin{aligned}
& \text { ma'=sha natan-a' } \\
& \text { what }=\text { INDEF hear.IND.1 MIN } \\
& \text { I heard something. }
\end{aligned}
$$

Notebook 2: p. 32

5. conditional protasis

$$
\begin{array}{lll}
\text { in=sha } & \text { ni'-patan } & \text { sha'wi-tuku } \\
\text { who=INDEF } & \text { see-SEQ.2MIN } & \text { tell-IMP.SG } \\
\text { If you see someone, tell me. } &
\end{array}
$$

Notebook 2: p. 33 


\section{ULLOA - FUNCTIONAL TYPOLOGICAL APPROACH TO SHAWI...}

7. direct negation

$\begin{array}{lll}\mathrm{ku} & \text { in=sha } & \text { nitu-te-rin=we } \\ \mathrm{NEG} & \text { who=NEG.INDEF } & \text { know-VM-IND.3MIN=NEG }\end{array}$

No one knows.

Notebook 2: p. 33

$\begin{array}{lll}\mathrm{ku} & \text { insu=nta } & \text { nitu-te-rin }=\text { we } \\ \mathrm{NEG} & \text { who=NEG.INDEF } & \text { know-VM-IND.3 } \mathrm{MIN}=\mathrm{NEG}\end{array}$

No one knows.

Notebook 2: p. 33

8. indirect negation

$\begin{array}{lllr}\mathrm{ku} \quad \text { nate-rawe } & \text { in=sha } & \text { nitu-te-rin-su } \\ \text { NEG believe-IND.1MIN } & \text { who=INDEF } & \text { know-VM-IND.3MIN-REL } \\ \text { I do not think anyone knows. } & \text { Notebook 2: p. 33 }\end{array}$

9. free choice

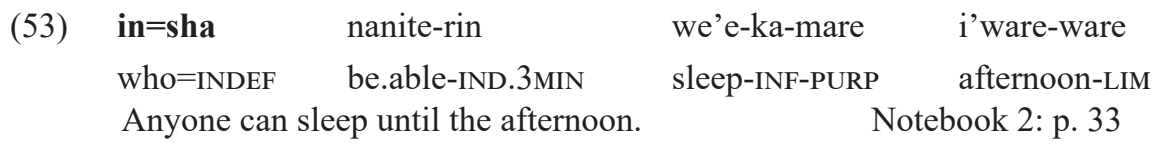

\section{The scalar focus marker}

In Shawi, when an indeterminate pronoun is under the scope of negation it bears the suffix $=n t a$ ', which alternates with =teranta'. The former is used elsewhere in the language to mean 'also' or 'in addition to', while the latter means 'even'. Although the particle teranta' is not decomposable synchronically, it is diachronically. Because the reflex of this word in Shiwilu is ta 'la (Bendor-Samuel 1958: 83), it stands to reason that in Shawi teranta' is diachronically composed of tera and - $n t a$ '. In example (54) $=n t a$ ' is used to mean also, while in (55) it is used to compose 'nothing'. In (56), the variant =teranta' is used.

$$
\begin{array}{lll}
\text { taya } & \mathrm{ka}=\mathrm{ri}=\mathbf{n t a}^{\prime} & \text { tepa-ra' } \\
\text { crocodile } & 1 \mathrm{MIN}=\mathrm{ERG}=\text { also } & \text { kill-IND.1MIN }
\end{array}
$$

I also killed a crocodile.

Notebook 1: p. 95 b

$$
\begin{array}{llll}
\text { (55) } & \text { ma=nta' } & \text { yawe-te-rin-ku=we } \\
\text { NEG } & \text { what=NEG.INDEF } & \begin{array}{l}
\text { exist-VM-IND.3MIN-OBJ.1 } 1 \text { MIN=NEG } \\
\text { I have nothing (lit. nothing exists for me). }
\end{array} & \text { Notebook } \\
\text { (56) } & \text { ku } & \text { inseke=teranta } & \text { pan-in=we } \\
\text { NEG } & \text { where=NEG.INDEF } & \text { go-IND.3MIN=NEG }
\end{array}
$$$$
\text { I have nothing (lit. nothing exists for me). } \quad \text { Notebook 1: p. } 58
$$

He did not go anywhere / He went nowhere. Notebook 1: p. 64 
This raises a question: why should a clitic meaning ‘also/even' attach to indeterminates in negative contexts? In seeking an explanation for this, we turn to Haspelmath's (1997) typological work on indefinite pronouns. Following the discussion on (157-164), we see that Shawi is not alone. As it turns out, indefinite pronouns can be diachronically derived by taking an interrogative pronoun and attaching: additive particles like 'also' (as in Hittite, Even, Kannada, etc.), and scalar particles like 'even' (as in Selkup, Nivkh, Japanese, etc.) or 'at least' (as in Finnish, Hungarian, Lezgian, etc.). Moreover, the indefinites created from the combination of interrogative pronouns and these particles are often used for negative functions (imagine that something like what-even meant nothing and/or anything). In this way, Shawi indeterminates under the scope of negation behave like indefinite pronouns.

To explain why particles like 'also', 'even', or 'at least' should become markers of indefiniteness in pronouns, Haspelmath (1997: 111-118, 163-164) turns to the work on pragmatic scales, and (pragmatic) scalar implicatures.

Scalar focus particles like 'even' characterize their focus value as ranking low in an ordered pragmatic scale. As Haspelmath (1997: 111) points out, in a sentence like, Natasha even speaks Dutch, it is implied that Dutch is an unlikely language for Natasha to know and thus is ranked as the last possible language that one could imagine her knowing. Thus, scalar focus particles give rise to scalar implicatures by placing a focused value at the endpoint of a pragmatic scale. Additive particles like 'also' (cf. König 1991: 68, cited in Haspelmath, 1997: 157) often have a scalar value too, and Haspelmath mentions, "it is not necessary or even possible to strictly separate the meanings 'also' and 'even"' (ibid).

Scalar implicatures are those which arise out of an utterance like, The weakest man could pick this up. In such a sentence the implicature is that all other men should be able to pick up this item. Thus, scalar implicatures give the sense of universal quantification through pragmatic inference, not semantic entailment. It should be noted that this can only be done with a superlative which denotes the lowest point on a pragmatic scale; a sentence like The strongest man could pick this up does not give rise to such an implicature of universality.

Another pragmatic phenomenon known as scale reversal cancels the universal implicature set up by a low superlative through negation, e.g. The weakest man could not pick this up. Such a sentence does not give us any implicatures about the ability of other men being able to pick up an item. On the other hand, scale reversal can set an implicature of universality with a superlative on the other side of the scale, e.g. The strongest man could not pick this up (Haspelmath 1997: 113). That sentence implicates that no other man could pick up the item in question, and thus universally quantifies from a reversed scale.

As we can see, additive particles, scalar focus particles, and negation all share the property of placing scalar implicatures in words under their scope; and also denote the low point on such a scale (see ex. 34). Moreover, since indefinite pronouns carry minimal semantic content the negation of a sentence like John saw something to John didn't see anything carries the implicature that John saw nothing, especially if reinforced by scalar focus particles (Haspelmath, 1997: 164). Therefore, it does not seem to be an accident that negative indefinites often occur with scalar focus particles.

While the fact that Shawi uses 'even/also' to mark negative indeterminates seems confusing, it becomes easier to understand if one takes scalar implicatures and scalar reversal into account. Furthermore, it appears that when the element $=n t a$ ' is attached to 


\section{ULLOA - FUNCTIONAL TYPOLOGICAL APPROACH TO SHAWI...}

an indeterminate pronoun, its meaning as a scalar focus particle has become bleached. In other words, the meaning of $=n t a$ ' in indeterminate pronouns has changed from that of a particle which expresses a pragmatic function to that of a grammatical marker of negative indefiniteness.

\section{Free relatives}

As discussed in section 3.3, free relative clauses or FRs are defined by Caponigro, Torrence \& Cisneros (2013) through the three following properties.

(i) Lexical property: FRs must contain a wh-word

(ii) Syntactic property: FRs are embedded clauses with a gap in argument or adjunct position

(iii) Semantic property: FRs can always be replaced with truth conditionally equivalent NPs or PPs (or oblique or adverbial constituents)

In a corpus of texts collected by the author, free relatives are formed by using the interrogative marker $=t a$ '. While they satisfy both the lexical and syntactic requirements, more investigation has to be done to find out if they meet the semantic requirement. Examples (57) to (60) below, present the use of $=t a$ '.

\begin{tabular}{|c|c|c|c|}
\hline (57) $\mathrm{ka}$ & kapeita-’i & in $=$ ta & \\
\hline 1MIN.EXCL & be.awake-JUs.1MIN.EXCL & who $=$ INT & \\
\hline napu-te-rin-pu-su & shipi-ta-tun & & shipi-ta-tun \\
\hline do-VM-IND.3MIN-OBJ.1 MIN.INCL-R & REL wet-VM-SUB.3MIN & & wet-VM-SUB.3MIN \\
\hline pate ${ }^{17}$-rin-pu & iseke & kema & yawe-rin=we \\
\hline leave-IND.3MIN-OBJ.2MIN.INCL & here & aguaruna & exist-IND. $3 \mathrm{MIN}=\mathrm{NEG}$ \\
\hline
\end{tabular}

I will stay awake [to find out] who's making us wet, there are no Aguaruna here. The achiote and huito sisters, 03:44 ${ }^{17}$

$\begin{array}{lll}\text { ma }=\text { ta } & \text { sha'wi-ch-i-nke } & \text { ipura } \\ \text { what }=\text { INT } & \text { tell-VM-JUS.1MIN.EXCL-OBJ.2MIN } & \text { now }\end{array}$

What I will tell you now...

Of how Shawi come from parrots, 01:04
(59) nanin nitute-rin pa'p-in unpuru=ta u'ma-rin-su
already know-IND.3MIN father-POsS.3MIN when=INT return-IND.3MIN-REL
He already knew when his father would return.

The owl that became human v2, 04:07

\footnotetext{
${ }^{17}$ Spanish calque. There's a common resultative construction 'dejar X' (leave X).
} 


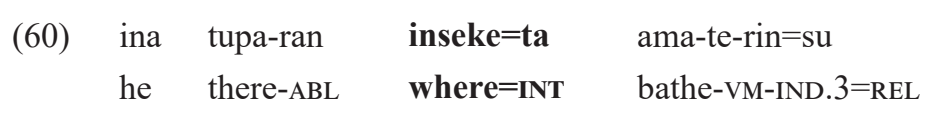

He searched all over, [he went] where they bathed her (and did not find her)

The achiote and huito sisters 11:13

In (57) to (60) the free relative clauses are subordinate have gaps and have the same form as interrogatives. Thus, the lexical and syntactic properties are satisfied. Although it is unclear if these constructions satisfy the semantic property, it is very likely that they do. For instance, in the examples above inta, mata, unpuruta, and inseketa, could all probably be replaced by piyapi (person), nanan (news, Hart 1988: 117), taweri (day), and isha (river), respectively. Because verbs can be relativized morphologically, relative clauses that may translate into FRs in English do not always need an interrogative as in (61).
(61) tepa-ran $=\mathbf{s a} \quad$ panka
kill-IND. $2 \mathrm{MIN}=$ REL big
What you killed is big.

Notebook 2: p. 31

Next only two of the three kinds of FRs that "have been discussed in the literature and are attested cross-linguistically" (Caponigro; Torrence \& Cisneros 2013: 74) will be described. These are definite FRs (section 8.1), and -ever FRs (section 8.2). The last of these, existential FRs were not found in the corpus.

\subsection{Definite FRs}

According to Caponigro; Torrence \& Cisneros (2013), the most common kind of FRs are those that can be replaced or paraphrased with a definite NP or PP. These are called definite FRs. For example, in English what in I'll take what you have can be replaced giving, I'll take the thing you have. All examples in the previous section are definite FRs, as are the ones in (62) to (64).

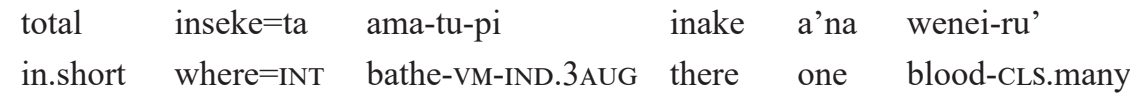
So, he looked where they bathed her and there he found her blood.

The achiote and huito sisters 11:54

$$
\begin{aligned}
& \text { ma }=\text { ta ka-su ya'kari-rin-ku } \\
& \text { what }=\text { INT 1MIN.EXCL-FOC be.close-IND.3MIN-OBJ.1MIN.EXCL } \\
& \text { What got close to me... } \\
& \text { Filmer finds the mother spirit of the forest, } 03: 48
\end{aligned}
$$


ULLOA - FUNCTIONAL TYPOLOGICAL APPROACH TO SHAWI...

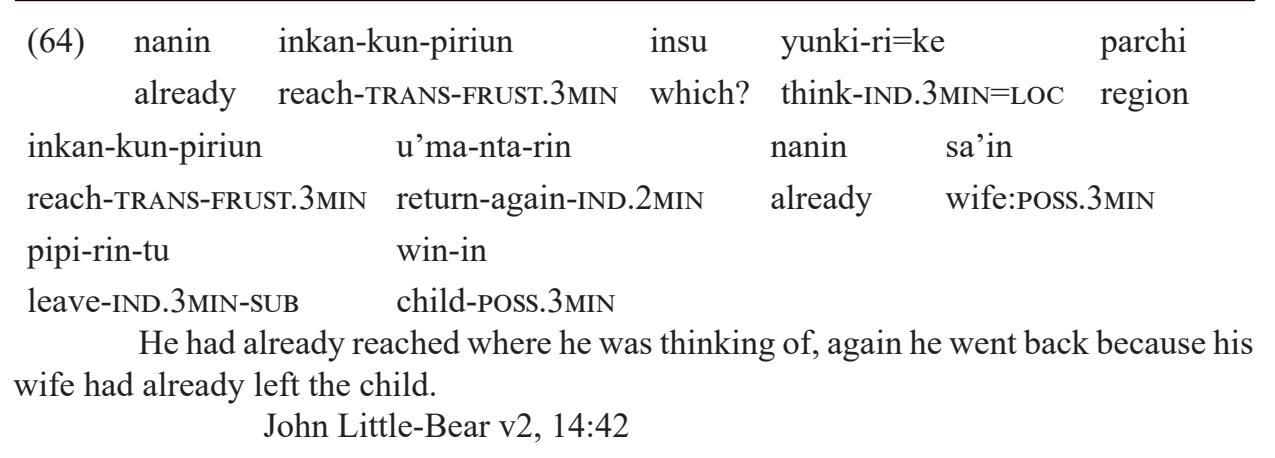

\section{2. -ever FRs}

These are defined in Caponigro; Torrence \& Cisneros (2013: 75) as "FRs whose wh-words are morphologically or syntactically modified by what in English looks like the suffix -ever. The morphosyntactic marking is associated with a change in the syntactic and semantic behavior or the FRs, although correct description and account for such a change are still debated." Tredinnick (2005) argues that for English, suffixation of -ever in an FR allows it to be interpreted as definite in episodic contexts, and as universal in generic contexts. Additionally, she argues that -ever also has modal properties, allowing an ignorance reading in an epistemic modal base and an indifference reading in a counterfactual modal base. It is not clear to what extent this is true in Shawi, but in (65) $=t a$ giving a universal reading, while in (66) we see =tana giving a definite reading. However, these are the only two examples so more investigation has to be done before making definitive conclusions.

$$
\begin{aligned}
& \text { shipi-ru=ke ya'we-pun intupa }=\text { ta } \quad \text { ya'we-pun } \\
& \text { aguaje-cls.many=loc exist-pot. } 2 \mathrm{~min} \quad \text { whither }=\mathrm{INT} \quad \text { exist-pot. } 2 \mathrm{~min} \\
& \text { In aguaje orchards you will live, wherever you are you will live. }
\end{aligned}
$$

The achiote and huito sisters: 35:00

$$
\begin{aligned}
& \text { insu=tana nuwante-ran }=\text { su ma-ke } \\
& \text { which=EVER? want-IND. } 2 \text { MIN=REL grab-IMP.SG } \\
& \text { You can grab whichever [one] you want. Notebook 2: p. } 33
\end{aligned}
$$

\section{Constructions with $=s u$}

In the NT corpus all FRs were composed with $=s u$ instead of $=t a$. As Rojas-Berscia (2019a, 2019b) describes, this element is used in various grammatical constructions and across word classes. However, the indeterminates with $=s u$ were difficult to elicit. This may be due to the difficulty speakers have to come up with constructions like this in a nonnatural setting. Perhaps it could be due to $=s u$ ' and =suna falling out of use in Cahuapanas or never having been part of the grammar there. There were some examples elicited using 
the clitic $=s u^{\prime}$ on indeterminate pronouns, they seem to have different uses. In (67) and $(68),=s u$ ' is used to code what appears to be an indefinite pronoun, ${ }^{18}$ while in (69) it is used as an -ever FR and not a definite one, cf. section 8.1. In (70) to (71), we see $=s u$ ' being used, but this may be due to the presence of the dubitative mood.

$$
\begin{aligned}
& \text { mikiri } \quad \mathbf{m a}^{\prime}=\mathbf{s u} \mathbf{}^{, 19} \quad \text { man-in } \\
& \text { Miguel what }=\text { REL } \\
& \text { grab-IND.3MIN } \\
& \text { Miguel grabbed a(n unknown) thing. }{ }^{19}
\end{aligned}
$$

Notebook 1: p. 57

$$
\begin{array}{ll}
\begin{array}{ll}
\text { unpuru=su' } & \text { kenan-patu } \\
\text { when=rel } & \text { find-seq.1 } 1 \text { min.excl }
\end{array} \\
\begin{array}{ll}
\text { Someday, when I find it, I will grab } \\
\text { unpuin=su } & \text { ma-ke } \\
\text { how=REL } & \text { grab-IMP.AUG }
\end{array}
\end{array}
$$

Someday, when I find it, I will grab it.

\author{
ma'-sa-ra \\ grab-prog-IND.1MIN.EXCL \\ Notebook 1: p. 69
}

(69) unpuin $=$ su ma-ke

Grab it however.

Notebook 1: p. 68

$$
\begin{array}{ll}
\text { ¿intupa }=\text { su } & \text { pa-sa-mara } ? \\
\text { to.where=REL } & \text { go-PROG-DUB.3MIN }
\end{array}
$$

Where might she be going to?

Notebook 1: p. 68
(71) ¿unpuru=su wen-tu-mara?
when $=$ REL come-VM-DUB.3MIN

When might he have come?

Notebook 1: p. 68

Only one example using =suna was able to be elicited. It was rarely used or grammatical. However, replacing =sun $a$ with $=$ tana made the sentence grammatical (cf. examples 73 and 74) This raises the question of whether there is a morpheme -na.

$$
\begin{aligned}
& \text { ma'=suna napa-rin apunin } \\
& \text { what=EVER? Say:PROG-IND.3MIN bad } \\
& \text { What (ever?) he is saying is bad. }
\end{aligned}
$$

Notebook 2: p. 32

$\begin{array}{lll}\text { *insu=suna } & \text { nuwante-ran=su } & \text { ma-ke } \\ \text { which=EVER } & \text { want-IND.2MIN=REL } & \text { grab-IMP.SG } \\ \text { *You can grab whichever [one] you want. } & \text { Notebook 1: p. } 67\end{array}$

${ }^{18}$ This is also noted in Rojas-Berscia (2019a: 137)

${ }^{19}$ This word is used for hesitation in speech, similar to 'um' or 'ehm' (see ex. 28). Another word used for this function is isu, which is a calque from Spanish este (this), also used for hesitation. This leads one to wonder if $m a$ 'su is an archaic calque for este. 


\section{ULLOA - FUNCTIONAL TYPOLOGICAL APPROACH TO SHAWI...}

(74)

$\begin{array}{lll}\text { insu=tana } & \text { nuwante-ran=su } & \text { ma-ke } \\ \text { which=EVER } & \text { want-IND.2MIN=REL } & \text { grab-IMP.SG }\end{array}$

You can grab whichever [one] you want. Notebook 2: p. 33

Nonetheless, Rojas-Berscia (2019a: 122) presents an example repeated below as (75).
insu'-pei $=\mathrm{ke}=$ suna
ma'sha ya'we-rin.
which-house $=$ LOC $=$ EVER
animal exist-IND.3MIN
There are animals in whichever [any] house.

\section{Other uses}

Indeterminates in Shawi definitely have another use and may have one more still. The other use they unquestionably have is the exclamative use, and the one that is up for debate is its use as an affirmative.

\subsection{Exclamative use}

In (76), we see the use of the base ma- along with the interrogative clitic $=t a$ to modify 'good.' It is unclear if -su is obligatory in this construction. In the NT, =cha is used instead; could $=k a$ be used here either in conjunction $=t a$ or in place of it here?

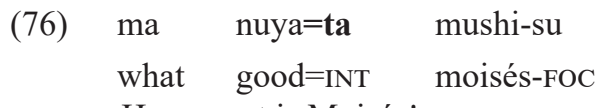

How great is Moisés! Notebook 1: p. 57

\subsection{Affirmative uses?}

In Shawi, there is a word inta, which is quite often used to mean something like 'okay, 'well,' or 'let's see here'. In (77), we see that use. There is no reason to think that something like this would be related to indeterminates, but the example in (78) we see incha, which in turn may be related to the rhetorical marker reported by Hart (1988). 


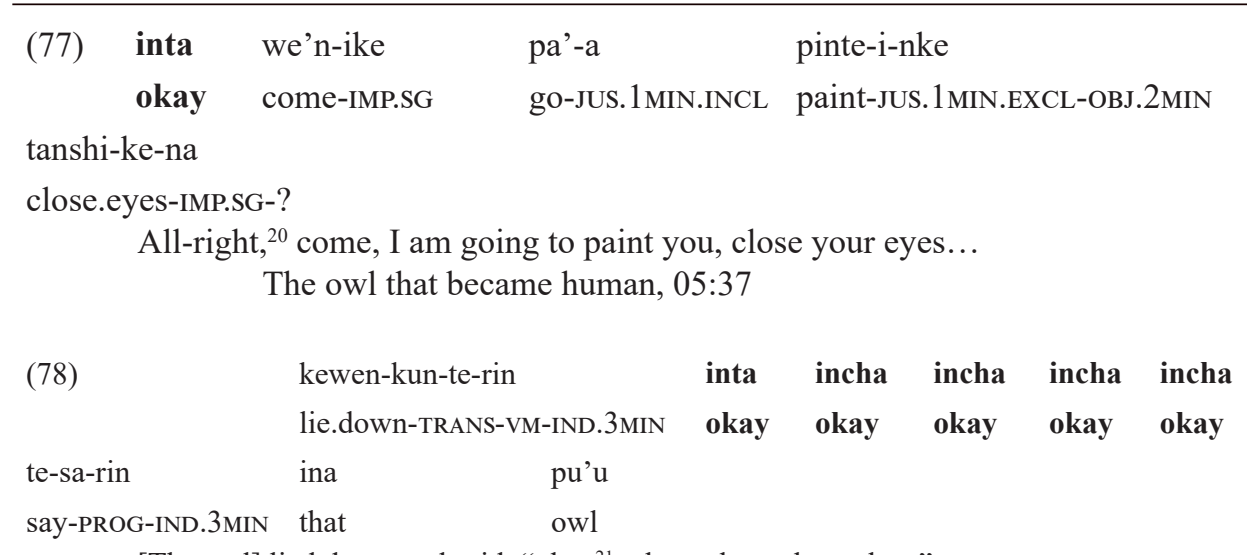

[The owl] lied down and said: "okay ${ }^{21}$, okay, okay, okay, okay."

The owl that became human, 02:11

\section{Concluding remarks}

This paper has gone over the formal and functional properties of indeterminate pronouns in Shawi. To summarize, we have seen that indeterminate pronouns share the same ontological bases (roots) across different functions like interrogative, indefinite, negative indefinite, and free relatives. Furthermore, other functions like the marking of rhetorical questions and exclamatives were explored. It is clear from this investigation that interrogatives, indefinites, and free relatives all share a central notion, which Bhat (2004: 227) calls informational gap. Thus, in Shawi indeterminate pronouns convey an informational gap, and indeterminate clitics specify the kind of gap.

There are still questions that need to be answered and thus require further research. For instance, what is the status of $=s u$ among indeterminates? If it is indeed acquiring indefinite functions, what are they? Would they fill the gaps in $\S 6$ ? If the polar/rhetorical question marker $=k a$ is unique to Cahuapanas Shawi, then how are these constructions formed in the Sillay and Paranapura varieties? Do they use $=c h a$ as reported by Hart (1988)? Since $=k a$ was borrowed from Aguaruna, do they share more properties when it comes to indeterminates? Furthermore, as Valenzuela (2015: 41) reports, Shiwilu and Quechua form questions in a similar fashion and have similar interrogative forms, as illustrated in (79) and (80). Although Aymara does not share the form of the element, it does have the same construction as in (81). How many other languages, including those mentioned in Wise (2011), share this behavior? What are the similarities and differences?

Shiwilu (Valenzuela et al. 2014: 41)

$$
\begin{aligned}
& \text { ¿ma'nen a'ta' ñinchi-t-etchek? } \\
& \text { what INT know-VM-FUT.1sG } \\
& \text { What will I find out about? }
\end{aligned}
$$

\footnotetext{
${ }^{20}$ Translated from Spanish "A ver."

${ }^{21}$ Translated from Spanish "ya."
} 
ULLOA - FUNCTIONAL TYPOLOGICAL APPROACH TO SHAWI...

San Martín Quechua (Coombs et al., 1976: 68)

(80) ¿pi-wan-tak shamu-nki?

who-COM-INT come-PRs.2

Who are you coming with?

Aymara (Hardman, 2001: 173)

(81) qhawqha punchu-ma-s ut-ji

how.many poncho-Poss.2-INT exist-3 $>3$

How many ponchos do you have? (lit. How many ponchos exist for you?) 


\section{Appendix A: Table of indeterminates}

In the table below, all the possibilities for indeterminates examined by the author are listed. In the first column the English translation is rendered, followed by the ontological base and then by all the possible clitics that can attach. The three dashes mean that attaching the indeterminate clitic onto the ontological base is not possible. Question marks mean it is unknown if this would be a possible pronoun.

Thus, the base in-ken- (whose) (on the sixth row) can take $=t a$ (interrogative) and =teranta (negative indefinite), forming inkenta and inkenteranta, but it cannot take $=s h a,=$ tana, nor $=s u$. In other words, inkensha, inkentana, nor inkensu are not possible indeterminate pronouns. In the second row, the specific forms for the category of person are listed since the base is different for the negative indefinite. The clitics that unpan(why) can take have not been looked into yet.

Parenthesis around a lowercase segment means that it is optional. The parenthesis around $\mathrm{N}$ and $\mathrm{V}$ mean that nouns and verbs, respectively, can optionally occur there. Finally, the uppercase TAM means that verbal morphology must go here.

\begin{tabular}{|c|c|c|c|c|c|c|}
\hline ENGLISH & $\begin{array}{l}\text { ONTOLOGICAL } \\
\text { BASE }\end{array}$ & INTERROGATIVE* & INDEFINITE & $\begin{array}{l}\text { NEGATIVE } \\
\text { INDEFINITE }\end{array}$ & $\begin{array}{l}\text {-EVER } \\
\text { RELATIVE }\end{array}$ & $=s u$ \\
\hline who & in(-su)- & inta & insha & insunta & intana & --- \\
\hline who (pl) & in-pita- & $=\mathrm{ta}$ & --- & $=$ teranta & --- & --- \\
\hline who (erg) & in-kari- & $=\mathrm{ta}$ & --- & $=$ nta & $=\tan a$ & $=\mathrm{su}$ ' \\
\hline with whom & in-eke- & $=\mathrm{ta}$ & --- & --- & $=\tan a$ & $=\mathrm{su}$ ' \\
\hline whose & in-ken- & $=\mathrm{ta}$ & --- & $=$ teranta & --- & --- \\
\hline which & in-su-(N-) & $=\mathrm{ta}$ & --- & $=$ teranta & $=\tan a$ & $=\mathrm{su}$ ' \\
\hline which (pl) & in-su-pi(ta)- & $=\mathrm{ta}$ & --- & $=$ teranta & $=\tan a$ & --- \\
\hline where & inse-ke- & $=\mathrm{ta}$ & --- & $=$ teranta & $=\tan a$ & $=\mathrm{su}$ ' \\
\hline from where & inse-ran- & $=\mathrm{ta}$ & --- & $=$ teranta & $=\tan a$ & --- \\
\hline whither & intupa- & $=\mathrm{ta}$ & --- & $=$ teranta & $=\tan a$ & $=\mathrm{su}$ ' \\
\hline until where & intupa-ware- & $=\mathrm{ta}$ & --- & $=$ teranta & $=\tan a$ & --- \\
\hline what & ma'-(N-) & $=\mathrm{ta}$ & $=$ sha & $=$ nta & $=\tan a$ & $=\mathrm{su}$ ' \\
\hline what (erg) & ma-kari- & $=\mathrm{ta}$ & $?$ & $?$ & $?$ & $?$ \\
\hline for what & ma'-mare- & $=\mathrm{ta}$ & --- & $=$ teranta & $=\tan a$ & --- \\
\hline with what & ma-ke- & $=\mathrm{ta}$ & --- & $=$ teranta & $=\tan a$ & $=\mathrm{su}$ ' \\
\hline do what & unpu-TAM- & $=\mathrm{ta}$ & --- & --- & $=\tan a$ & --- \\
\hline how much & unpu-(N-) & $=\mathrm{ta}$ & --- & $=$ teranta & $=\tan a$ & $=\mathrm{su}^{\prime}$ \\
\hline when & unpu-ru & $=\mathrm{ta}$ & --- & $=$ teranta & $=\tan a$ & $=\mathrm{su}$ ' \\
\hline how & unpu-in- & $=\mathrm{ta}$ & --- & --- & $=\tan a$ & $=\mathrm{su}$ ' \\
\hline how do $\mathrm{X}$ & unpu-(V) & $=\mathrm{ta}$ & $?$ & $?$ & $?$ & $?$ \\
\hline why & unp-an- & $=\mathrm{ta}$ & $?$ & $?$ & $?$ & $?$ \\
\hline
\end{tabular}




\section{ULLOA - FUNCTIONAL TYPOLOGICAL APPROACH TO SHAWI...}

References

Barraza, Yris Julia (2005). El sistema verbal en la lengua Shawi (Tese de doutorado). Universidade Federal de Pernambuco. https://repositorio.ufpe.br/handle/123456789/7747

Base de Datos de Pueblos Indígenas u Originarios. Pueblo Shawi. Retrieved from (https://bdpi.cultura.gob.pe/ sites/default/files/archivos/pueblos indigenas/Shawi 0.pdf) (Accessed 17/10/2019)

Bhat, D. N. S. (2004). Pronouns. Oxford: Oxford University Press.

Bendor-Samuel, John T. (1981[1958]). The structure and function of the verbal piece in the Jebero language (Ph.D. dissertation). University of London, School of Oriental and African Studies. Lima: Ministerio de Educación e Instituto Lingüístico de Verano. Available at: http://www.peru.sil.org/resources/archives/9563

Beuchat, Henri; Rivet, Paul (1909). La Famille Linguistique Cahuapana. Zeitschrift für Ethnologie. XLI: 616-634.

Cárdenas Sanchez, Rene (Speaker); Segundo Pinedo Escobedo (Translator); and Luis Ulloa (Researcher) (2017b). Text 2017 - The fox and the star-woman. Shawi Collection of Luis Ulloa. The Archive of the Indigenous Languages of Latin America, ailla.utexas.org. Access: public. PID ailla:119783. Accessed October 22, 2019.

Caponigro, Ivano; Torrence, Harold; Cisneros, Carlos (2013). Free relative clauses in two Mixtec Languages. International Journal of American Linguistics 79(1): 61-96.

Chanchari Santillan, Riquelmer Tony (Speaker); Segundo Pinedo Escobedo (Translator); and Luis Ulloa (Researcher) (2017b). Text 2017 - Kunpanama and the whale. Shawi Collection of Luis Ulloa. The Archive of the Indigenous Languages of Latin America, ailla.utexas.org. Access: public. PID ailla:119783. Accessed October 22, 2019.

Coombs, David M.; Coombs, Heidi; Weber, Robert L. (1976). Gramática quechua: San Martín. Lima: Ministerio de Educación.

Crevels, Mily (2007). South America. In Christopher Moseley (ed.). Encyclopaedia of the World's Endangered Languages, pp. 101-194. London/New York: Routledge.

Donaldson, Tamsin (1980). Ngiyambaa: The language of the Wangaaybuwan (Cambridge Studies in Linguistics, 29.) Cambridge: Cambridge University Press.

Escobedo Padilla, Antonio (Speaker); Segundo Pinedo Escobedo (Translator); and Luis Ulloa (Researcher) (2018b). Text 2018 - The woman and the iguana-man. Shawi Collection of Luis Ulloa. The Archive of the Indigenous Languages of Latin America, ailla.utexas.org. Access: public. PID ailla:119783. Accessed October 22, 2019.

Fuentes, Aldo (1988). Porque las piedras no mueren: Historia, sociedad y ritos de los Chayahuitas del alto Amazonas. Lima: Centro Amazónico de Antropología y Aplicación Práctica.

Hardman, M.J. (2001) Aymara (LINCOM Studies in Native Linguistics, 36) Munich: LINCOM EUROPA.

Hart, George; Hart, Helen; Powlison, Esther (1976). La fonología de Chayahuita. Lima: Instituto Lingüístico de Verano. 
Hart, Helen L.; Hart, George (1981). La cohesión en el texto narrativo del chayahuita. In Wise, Mary Ruth; Anne Stewart (eds.). Cohesión y enfoque en textos y discursos, pp. 48-151. Lima: Ministerio de Educación e Instituto Lingüístico de Verano.

Hart, Helen L. (1988). Diccionario chayahuita-castellano (Canponanque nisha nisha nonacaso') (Serie Lingüística Peruana, 29.) Yarinacocha: Ministerio de Educación e Instituto Lingüístico de Verano.

Hart, Helen L.; Púa P., Raimundo; Púa C., Eduardo (1996). Mashocoro 'sa'topiso'(Leyendas de los chayahuita) (Comunidades y Culturas Peruanas, 27.) Pucallpa: Ministerio de Educación y Instituto Lingüístico de Verano.

Haspelmath, Martin (1997). Indefinite pronouns. Oxford: Oxford University Press.

Hidalgo Chanchari, Filmer (Speaker); Segundo Pinedo Escobedo (Translator); and Luis Ulloa (Researcher) (2018). Text 2018 - Filmer finds the mother spirit of the forest. Shawi Collection of Luis Ulloa. The Archive of the Indigenous Languages of Latin America, ailla.utexas.org. Access: public. PID ailla:119783. Accessed October 22, 2019.

Hidalgo Chanchari; Rosi Genia (Speaker); Segundo Pinedo Escobedo (Translator); and Luis Ulloa (Researcher). (2017). Text 2017 - The owl that became human. Shawi Collection of Luis Ulloa. The Archive of the Indigenous Languages of Latin America, ailla.utexas.org. Access: public. PID ailla:119783. Accessed October 22, 2019.

Inuma Marín, Pedro (Speaker); Segundo Pinedo Escobedo (Translator); and Luis Ulloa (Researcher) (2018a). Text 2018 - Of how Shawi come from parrots. Shawi Collection of Luis Ulloa. The Archive of the Indigenous Languages of Latin America, ailla.utexas.org. Access: public. PID ailla:119783. Accessed October 22, 2019.

Jackendoff, Ray (1983). Semantics and cognition. Cambridge: MIT Press.

La Liga Bíblica (2008). Yosë Nanamën, Quisocristo Anitotërinoasu': El Nuevo Testamento de nuestro Señor Jesucristo en el idioma chayahuita (2nd edition).

Pinedo Escobedo, Segundo (Speaker, Translator); and Luis Ulloa (Researcher) (2017b). Text 2017 - The owl that became human v2. Shawi Collection of Luis Ulloa. The Archive of the Indigenous Languages of Latin America, ailla.utexas.org. Access: public. PID ailla:119783. Accessed October 22, 2019.

Rivet, Paul; Tastevin, Constant (1931). Nouvelle contribution à l'étude du groupe Kahuapana. International Journal of American Linguistics 6(3/4): 227-271.

Rojas-Berscia, Luis Miguel (2013). La sintaxis y semántica de las construcciones causativas en el chayahuita de Balsapuerto (Licenciate tesis). Lima, Perú: Pontificia Universidad Católica del Perú. Available at: http:// hdl.handle.net/20.500.12404/4670

Rojas-Berscia, Luis Miguel (2017). Review of Fritz, Samuel (?). El vocabulario de la lengua xebera, una doctrina cristiana en xebero y quechua, y la gramática de la lengua xebera (siglo XVIII). AlexanderBakkerus, Astrid (edición y estudio). Madrid/Frankfurt am Main: Iberoamericana Vervuert, 2016. Lexis (Peru) 40(2): 479-489

Rojas-Berscia, Luis Miguel (2019a). From Kawapanan to Shawi: Topics in language variation and change (Ph.D. dissertation). Nijmegen, Netherlands: Radboud University. Available at https://pure.mpg.de/rest/ items/item_3031970_5/component/file_3155071/content

LIAMES, Campinas, SP, v. 19, 1-28, e019017, 2019 


\section{ULLOA - FUnCTIONAL TYPOLOGICAL APPROACH TO SHAWI...}

Rojas-Berscia, Luis Miguel (2019b). Nominalization in Shawi (Chayahuita). In Roberto Zariquiey; Masayoshi Shibatani; David W. Fleck (eds.). Nominalization in the languages of the Americas, pp. 491-514. John Benjamins Publishing Company.

Sánchez Escobedo, Faustino (Speaker); Segundo Pinedo Escobedo (Translator); and Luis Ulloa (Researcher) (2017). Text 2017 - The achiote and huito sisters. Shawi Collection of Luis Ulloa. The Archive of the Indigenous Languages of Latin America, ailla.utexas.org. Access: public. PID ailla:119783. Accessed October 22, 2019.

Sánchez Escobedo, Faustino (Speaker); Segundo Pinedo Escobedo (Translator); and Luis Ulloa (Researcher). (2018a). Text 2018 - John Little-Bear v2. Shawi Collection of Luis Ulloa. The Archive of the Indigenous Languages of Latin America, ailla.utexas.org. Access: public. PID ailla:119783. Accessed October 22, 2019.

Sánchez Escobedo, Faustino (Speaker); Segundo Pinedo Escobedo (Translator); and Luis Ulloa (Researcher) (2018b). Text 2018 - The woman and the spirit of the stone. Shawi Collection of Luis Ulloa. The Archive of the Indigenous Languages of Latin America, ailla.utexas.org. Access: public. PID ailla:119783. Accessed October 22, 2019.

Sánchez Escobedo, Faustino (Speaker); Segundo Pinedo Escobedo (Translator); and Luis Ulloa (Researcher) (2018f). Text 2018 - Of the man that became the moon. Shawi Collection of Luis Ulloa. The Archive of the Indigenous Languages of Latin America, ailla.utexas.org. Access: public. PID ailla:119783. Accessed October 22, 2019.

Tredinnick, Victoria Ann (2005). On the semanics of free relatives with -ever (Ph.D. dissertation). Philadelphia, USA: University of Pennsylvania. Available at: https://www.ling.upenn.edu/ victoria/diss-dbl.pdf

Ulloa, Luis (Researcher); Segundo Pinedo Escobedo (Speaker, Translator) (2017). Field Notes 2017. The Shawi Collection of Luis Ulloa. Shawi Collection of Luis Ulloa. The Archive of the Indigenous Language of Latin America, ailla.utexas.org. Access: public. PID ailla: 119783. Accessed October 11, 2019.

Valenzuela, Pilar (2011a). Argument encoding and pragmatic marking of the transitive subject in Shiwilu (Kawapanan). International Journal of American Linguistics 77(1): 91-120. doi: 10.1086/657989

Valenzuela, Pilar (2011b). Contribuciones para la reconstrucción del proto-cahuapana: Comparación léxica y gramatical de las lenguas jebero y chayahuita. In Willem F.H. Adelaar; Pilar Valenzuela Bismarck; Roberto Zariquiey Biondi (eds.). Estudios en lenguas andinas y amazónicas. Homenaje a Rodolfo CerrónPalomino, pp. 271-304. Lima: Fondo Editorial Pontificia Universidad Católica del Perú.

Valenzuela, Pilar (2015). ¿Qué tan “amazónicas” son las lenguas kawapana? Contacto con las lenguas centroandinas y elementos para un área lingüistica intermedia. Lexis 39(1): 5-56

Valenzuela Bismark, Pilar; Meneleo Careajano Chota; Emérita Guerra Acho; Julia Inuma Inuma; Fernando Lachuma Cachique (2014) Kirka Llawer'lla'la Ñak, Diccionario Shiwilu-Castellano y CastellanoShiwilu. Lima: Federación de comunidades Nativas de Jeberos.

Wise, Mary Ruth (2011). Rastros desconcertantes de contactos entre idiomas y culturas a lo largo de los contrafuertes orientales de los Andes del Perú. In Willem F.H. Adelaar, Pilar

Valenzuela Bismarck; Roberto Zariquiey Biondi (eds.). Estudios en lenguas andinas y amazónicas. Homenaje a Rodolfo Cerrón-Palomino, pp. 305-326. Lima: Fondo Editorial Pontificia Universidad Católica del Perú.

Recebido: 1/6/2019

Versão revista e corregida: 25/10/2019

Aceito: $29 / 10 / 2019$ 